\title{
Косметичний ефект загоєння ран після хірургічного лікування зобу
}

\author{
О. П. Ковальов, О. М. Люлька, В. І. Ляховський, І. І. Немченко, А. В.Сидоренко
}

Українська медична стоматологічна академія МОЗ України, м. Полтава

\section{Cosmetic effect of the wounds healing after surgical treatment of goiter}

\author{
O. P. Kovalov, O. M. Liulka, V. I. Liakhovskyi, I. I. Nemchenko, A. V. Sydorenko \\ Ukrainian Medical Stomatological Academy, Poltava
}

\section{Реферат}

Мета. Оцінка загоєння післяопераційної рани і косметичного результату оперативного лікування хворих з різними формами зобу.

Матеріали і методи. Проаналізовані результати хірургічного лікування різних форм зобу у 2376 пацієнтів. 31973 по 1999 р. оперовано 1690 хворих (перший період дослідження), з 2000 по 2018 р. - 686 хворих (другий період дослідження). Оцінювали характер загоєння рани під час перебування хворого в стаціонарі і кінцевий косметичний ефект протягом 6 - 12 міс після виконання оперативного втручання.

Результати. Визначено чинники операційної техніки, необхідні для досягнення гарного косметичного ефекту. Запропоновано і впроваджено анатомічно орієнтовані доступи, оригінальні методики експозиції щитоподібної залози (Щ3), дренування і закриття рани після видалення або резекції ЩЗ для забезпечення іiі неускладненого загоєння і доброго кінцевого косметичного результату.

Висновки. Характер хірургічного доступу залежить від анатомічних даних та вимог косметичної хірургії. Екстрафасціальна методика видалення частки або всієї ЩЗ підвищує радикальність операції, сприяє гемостазу і неускладненому загоєнню рани. Запроваджений авторами доступ відповідає всім потребам хірургічного лікування даної патології.

ключові слова: щитоподібна залоза; зоб; хірургічне лікування; загоєння післяопераційної рани; косметичний ефект.

Abstract

Objective. Estimation of the postoperative wound healing and cosmetic result of operative treatment in patients with various kinds of goiter.

Materials and methods. Results of surgical treatment of 2376 patients, suffering various forms of goiter, were analyzed. From 1973 to 1999 yr 1690 patients were operated (first period of investigation), and from 2000 to 2018 yr - 686 patients (second period of investigation). There were estimated the character of the wound healing while stationary treatment of patients, and a definite cosmetic effect during 6-12 mo after performance of operative intervention.

Results. The features of operative technique, needed for achievement of fine cosmetic effect, were determined. There were proposed and introduced the anatomically oriented accesses, original procedures for the thyroid gland (THG) exposition, draining and closure of the wound after total or partial resection of THG for guaranteeing of its noncomplicated healing and favorable definite cosmetic result.

Conclusion. Character of surgical approach depends on anatomical data and demands for cosmetic surgery. Extrafascial procedure of partial or total resection of THG enhances the operation radicalism, promotes hemostasis and noncomplicated healing of the wound. The access, proposed by the authors, meets all needs of surgical treatment of this pathology.

Keywords: thyroid gland; goiter; surgical treatment; healing of postoperative wound; cosmetic effect.

В Україні виконують щороку до 12000 операцій на щитоподібній залозі (Щ3), і з кожним роком майже на 10\% зростає захворюваність на зоб, переважно на вузлові форми, серед яких частота виявлення пухлини становить 5\% [1-3].

Багато питань оперативного лікування різних форм зобу досі є дискусійними. Це стосується показань та радикалізму операції, особливостей оперативної техніки і необхідних заходів для запобігання розвитку специфічних ускладнень - ушкоджень гортанних нервів та прищитоподібних залоз [4 - 6]. Якщо уникнено таких ускладнень, на перший план, з точки зору оцінки пацієнтом професійної майстерності хірурга, виходить косметичний ефект операції. Погане загоєння рани подовжує тривалість післяо- пераційного періоду, погіршує косметичний ефект та негативно впливає на настрій хірурга і навіть знижує якість життя пацієнта. Враховуючи, що на зоб хворіють більше жінки, косметичний аспект хірургічного лікування цієї патології має особливе значення, а малопомітний післяопераційний рубець стає своєрідною "візитною карткою" хірурга [7, 8].

Загоєння рани і кінцевий косметичний результат залежать від низки факторів: віку хворого, порушення білкового обміну, підвищеної алергізації організму, генетичної схильності до утворення келоїдних рубців, індивідуальних особливостей шкіри [9]. Неабияку роль у цьому процесі відіграють і безпосередньо хірургічні чинники, обумовлені технікою і методикою виконання операції [10]. 
Мета дослідження: проаналізувати характер оперативних втручань на Щз, виконаних протягом тривалого часу, і визначити особливості оперативної техніки, урахування яких приводить до оптимального загоєння післяопераційної рани з досягненням гарного косметичного ефекту.

\section{Матеріали і методи дослідження}

Ми проаналізували 45-річний досвід оперативного лікування зобу в клініці кафедри хірургії № 1 Української медичної стоматологічної академії МОЗ України (м. Полтава). За цей час змінювалися як колектив хірургів, які брали участь у хірургічному лікуванні зобу, так і погляди на показання до операції, характер, об'єм і техніку оперативних втручань, хірургічні доступи для експозиції ЩЗ та методи закриття рани, що стало підставою для виділення декількох етапів, які мали суттеві відмінності за хірургічними підходами і технікою виконання оперативних втручань, що у свою чергу суттєво впливало на загоєння післяопераційної рани і кінцевий косметичний ефект. Крім того, було порівняно характер загоєння рани з методикою закриття операційної рани в різні періоди роботи.

Вважаємо, що отримання оптимального косметичного ефекту в значній мірі залежить від анатомічно обгрунтованого хірургічного доступу та його відповідності запланованій операції, об'єму і методики оперативного втручання, виду гемостазу і маніпуляцій з виконання мобілізації ЩЗ, методу дренування і закриття рани.

31973 до 2018 р. у клініці оперовано з приводу різних форм зобу та інших вогнищевих утворень ЩЗ 2376 хворих. У 1973 - 1999 рр. (перший період дослідження) виконано 1690 операцій, у 2000 - 2018 рр. (другий період дослідження) - 686. Проводячи аналіз, оцінювали характер загоєння рани під час перебування хворого в стаціонарі і кінцевий косметичний ефект через 6 - 12 міс після виконання операції. Під час перебування хворого у стаціонарі враховували такі параметри: наявність і ступінь набряку м'яких тканин у ділянці післяопераційної рани, наявність гіперемії шкіри, накопичення серозного (гнійного) ексудату в рані, необхідність пункційної евакуації вмісту рани і тривалість цих процедур, нагноєння рани, формування лігатурних нориць. У віддаленому періоді про якість післяопераційного рубця судили за такими критеріями: загальний малопомітний вигляд, лінійність та симетричність розташування, ступінь виступання над поверхнею шкіри, колір, товщина, нависання або втягнутість, ознаки келоїдного трансформування.

\section{Результати}

Основними особливостями оперативних втручань у першому періоді дослідження були: доступ за Кохером або комірцевоподібний з відшаруванням верхнього шкірно-підшкірного клаптя; пересічення та перев'язка передніх яремних вен та претиреоїдних м'язів; субфасціальна резекція ЩЗ (субтотальна або економна); гемостаз у ході операції кетгутом, шовком, капроном; дренування рани гумовими або марлевими смужками; закриття рани вузловими швами.

У післяопераційному періоді майже у половини пацієнтів спостерігали ознаки «хвороби відшарованого клап- тя»: набряк країв рани, довготривале (до 10 - 12 діб) накопичення в рані серозного чи серозно-гнійного ексудату, що потребувало пункційної евакуації вмісту рани, нерідко і після виписки хворого із стаціонару в амбулаторному порядку.

Поступово наші погляди стосовно показань до хірургічного лікування різних форм зобу, характеру оперативних втручань і методики іх виконання зазнали значних змін внаслідок аналізу діяльності провідних клінік, накопичення власного досвіду і впровадження новітніх хірургічних технологій.

У другому періоді спостереження ми визначили такі головні етапи операції.

Хірургічний доступ виконуємо за Кохером у модифікації клініки (деклараційний патент України на винахід № 42165А від 15.10.2011р.). Лінію розрізу шкіри маркуємо в передопераційній у положенні хворого стоячи 10\% розчином перманганату калію за допомогою гудзикового зонда з урахуванням особливостей анатомічної будови шиї пацієнта, розміру, форми і розташування Щз. Лінія маркування строго симетрична, трішки вигнута донизу, паралельна нижній шийній складці або збігається з нею, а у середній третині розташовується на 1,5 - 2 см вище вирізки грудини і досягає за наявності зобу II - III ступеня рівня внутрішньої третини грудинно-ключично-соскоподібного м'яза. Якщо зоб дуже великий, проводимо відповідну корекцію довжини і форми розрізу адекватно запланованій операції. За наявності дифузного токсичного зобу (ДТЗ) без значної деформації контурів шиї можна додатково визначити лінію розрізу вже на операційному столі, закинувши голову хворого, маркуванням за допомогою достатньо міцної капронової нитки. По раніше наміченій лінії або по нижній шийній складці шкіри віддавлюємо цією ниткою вузький жолобок з чіткими контурами. Маркування розрізу завершуємо нанесенням трьох вертикальних штрихів: двох - у кінцевих точках запланованого розрізу і одного - по центру. Ця деталь забезпечує оцінку симетрії розрізу і правильне формування внутрішньошкірного шва. Пацієнта вкладаємо на операційний стіл у такий спосіб, щоб висувний або окремий валик опинився під лопатками, а голова була закинута. Розріз виконуємо гострим скальпелем у строго перпендикулярному до шкіри напрямку, краще одним рухом - до платизми. Це в значній мірі запобігає виникненню у майбутньому розтягнутого по ширині післяопераційного рубця. Пересікаємо платизму. Верхній шкірно-підшкірно-фасціальний клапоть із попередньо пересіченими і перев'язаними передніми яремними венами відшаровуємо догори до рівня верхнього полюса більшої частки ЩЗ. Нижній клапоть відділяємо в тому ж анатомічному просторі до вирізки грудини. Відшаровуючи два шкірно-підшкірних клапті одним блоком із передніми яремними венами, ми зберігаємо в них гемо- та лімфомікроциркуляцію, значно збільшуємо операційний простір та уникаємо надмірної травматизації країв рани гачками.

Експозиції ЩЗ досягаємо у більшості спостережень поздовжнім роз'єднанням претиреоїдних м'язів по білій лінії від вирізки щитоподібного хряща до вирізки грудини. Кінцеві рівні розрізу варіабельні і залежать від розташу- 
вання Щ3 та їі розмірів. У пацієнтів з вираженим ожирінням та великими і малорухомими ЩЗ на короткій шиї претиреоїдні м'язи пересікаємо на рівні перешийка, а сформовані кукси віддавлюємо вказівними пальцями догори і донизу, що додатково збільшує доступ до ЩЗ.

Об'єм операції та методика видалення (резекціі) ЩЗ. Враховуючи онкологічні ризики за наявності вузлових форм зобу, аутоімунний характер захворювання на дТЗ та високу вірогідність рецидиву після операцій за резекційними методиками, ми стали віддавати перевагу радикальним методикам оперативних втручань - тиреоїдектомії (ТЕ) за наявності ДТЗ та багатовузлового зобу, гемітиреоїдектомії (ГТЕ) - за наявності вузлового ураження однієї частки щз.

У 2002 - 2006 рр. ГТЕ виконали у 41,5\% хворих 3 однобічним вузловим зобом, ГТЕ з резекцією контрачастки (ГТЕ + PK) - у 43,9\%, субтотальну резекцію частки Щ3 (СРЧ) - у 14,6\%, ТЕ - у 28,6\% хворих з багатовузловим зобом, ГТЕ + PK - у 43,2\%, СРЧ - у 30\%; субтотальну резекцію Щ3 (СРЩЗ) - усім хворим з ДТЗ.

За 2013 - 2018 рр. ГТЕ виконали у 86,5\% хворих з однобічним вузловим зобом, ГТЕ + РК - у 13,5\%, ТЕ - у 92,5\% хворих з багатовузловим зобом, ТЕ з центральною лімфодисекцією шиї - у 7,5\%; ТЕ - у 88,0\% хворих з ДТЗ, ГТЕ + РК - у $12 \%$ пацієнтів.

Потрібно пам'ятати, що кукси часток ЩЗ у разі застосування резекційних методик операції нерідко спричиняють кровотечу через прорізання швів. Все це може вкрай негативно відбитися на загоєнні рани і погіршити косметичний ефект операції.

32007 р. ми остаточно перейшли на застосування екстрафасціальної методики видалення (резекціі) Щ3. Екстрафасціальні маніпуляції на ЩЗ, якщо виконують ії мобілізацію із застосуванням прецизійної техніки і відповідного інструментарію, у значній мірі є профілактикою як ушкодження так званих структур ризику (гортанні нерви, прищитоподібні залози, суміжні органи), так і виникнення макро- та мікрогеморагії з утворенням крововиливів, формування кукс судин із залишком зайвої клітковини, яка зазнає некрозу і лізису.

Гемостаз. Необхідність виконання операції на щЗ у «сухому полі» не викликає дискусій. Гемостазу під час операції досягаємо прицільно точковою електрокоагуляцією капілярів і дрібних судин та перев'язкою тонкими капроновими нитками судин більшого калібру, уникаючи застосування розсмоктувального шовного матеріалу як додаткового джерела алергізації. За наявності у хворого келоїдних рубців після попередніх операцій (травм) або підвищеної алергізації організму застосування електрокоагуляції обмежуємо і уникаємо надмірного розтягнення шкіри гачками.

Рану орошаємо 5\% розчином епсилонамінокапронової кислоти для запобігання місцевому фібринолізу та виявлення в прозорому розчині непомічених кровоточивих дрібних судин, а у разі капілярної кровотечі на ділянку безпосередньо біля нижнього гортанного нерва застосовуємо гемостатичну губку. Контролюємо кінцевий гемостаз.

Методика дренування і закриття рани. Рану закриваємо пошарово. Роз'єднані претиреоїдні м'язи зшиваємо капроновими нитками, залишаючи отвір довжиною до 1,5 см у центрі лінії швів для дренажів. У разі пересічення претиреоїдних м'язів зшиваємо їх П-подібними швами із зануренням дорзальної поверхні кукс і прикриттям їх фасцією з наступним з'єднанням по середній лінії вузловими швами.

У такій спосіб досягаємо анатомічного і функціонального співвідношення тканинних структур шиї.

Через залишений м'язово-фасціальний отвір до ложа видалених часток (або частки) ЩЗ для дренування рани підводимо перехресно дві поліхлорвінілові трубки, діаметр яких відповідає діаметру катетера № 10, виводимо ï і фіксуємо в кутах рани. Отвори в них робимо так, щоб дренувати під- і надм'язовий фасціальні простори.

Зшиваємо платизму вузловими швами (капрон № 1), починаючи з місця центрального маркувального штриха. Накладаємо внутрішньошкірний шов поліпропіленовою ниткою № 3 затравматичною ріжучою голкою. Операцію завершуємо створенням у рані від'ємного тиску активною аспірацією [11]. Дренажі видаляємо на 1-шу добу, а внутрішньошкірний шов знімаємо на 4 - 5-й день після операції.

У ранньому післяопераційному періоді необхідно проводити лікувальну рухому гімнастику шиї, масаж лінії швів. Після виписки із стаціонару пацієнтам рекомендуємо продовжити зазначені заходи і для профілактики виникнення гіпертрофічних або келоїдних рубців протягом $1-2$ міс місцево застосовувати препарати, за дією подібні до контрактубексу або стратадерму.

\section{Обговорення}

Впровадження нових хірургічних підходів до виконання оперативних втручань з приводу різних форм зобу, застосування екстрафасціальної методики видалення частки або всієї ЩЗ із використанням прецизійної техніки на всіх етапах операції уможливили не тільки зниження частоти специфічних ускладнень (пошкодження нижніх гортанних нервів - до 0,9\%, транзиторного гіпопаратиреозу - до 1,8\%), а й запобігання ускладненому загоєнню післяопераційної рани: запаленню відшарованих клаптів, утворенню сером, гематом, нагноєнню рани.

Набряк з гіперемією шкіри у відшарованих під час операції шкірно-підшкірно-фасціальних клаптях спостерігали у 5 (0,73\%) хворих, а у 4 (0,58\%) хворих застосували пункційне випорожнення сероми. Нагноєння рани не було.

У першому періоді дослідження (1973 - 1999 рр.) косметичний ефект після операції протягом 6 - 12 міс простежили у 128 (7,6\%) пацієнтів: у 32 (25,0\%) із них його оцінили як добрий, у 68 (53,1\%) - задовільний, у 28 (21,9\%) - незадовільний, що проявлялося гіпертрофічними, розтягнутими по ширині та келоїдними рубцями.

Кінцевий косметичний ефект спостерігали у 132 (19,2\%) хворих, оперованих у другому періоді. Відмінним результат був у 21 (15,9\%), добрим - у 77 (58,3\%), задовільним - у 25 (18,9\%) пацієнтів. У 6 (4,5\%) пацієнтів сформувався гіпертрофічний, розтягнутий по ширині рубець, у 3 (2,3\%) - келоїдний. У решти хворих аналогічні зміни рубців виникли і після апендектомії. 


\section{Висновки}

1. Хірургічний доступ щодо операцій з приводу зобу необхідно планувати заздалегідь, враховуючи розмір і розташування ЩЗ, особливості будови шиї пацієнта і вимоги косметичної хірургіï.

2. Екстрафасціальна методика видалення частки або всієї ЩЗ підвищує радикальність операції, сприяє надійному гемостазу і кращому загоєнню ран.

3. Запроваджений нами доступ до ЩЗ є анатомічно орієнтованим, уможливлює добру експозицію органа і в поєднанні з прецизійною технікою виконання операції та запропонованою методикою дренування рани забезпечує неускладнене ії загоєння і добрий косметичний ефект операції.

\section{Підтвердження \\ Фінансування}

Фінансування роботи за рахунок авторів.

\section{Інформація про внесок кожного учасника}

Ковальов О. П. - дизайн дослідження, написання статті; Люлька О. М. - набір та аналіз матеріалу; Ляховський В. І. статистичне дослідження та аналіз матеріалу; Нємченко I. I. - збір та аналіз матеріалу; Сидоренко А. В. - оформлення статті та бібліографії.

Всі автори прочитали і схвалили остаточний варіант рукопису.

\section{Конфлікт інтересів}

Автори інформують про відсутність потенційних та явних конфліктів інтересів, пов'язаних з рукописом.

Згода на публікацію

Всі автори дали згоду на публікацію цього рукопису.

\section{References}

1. Rybakov SY, Shidlovskyi VO, Komisarenko IV, Pavlovskyi MP, editor. Tyreoidna khirurhiia. Ternopil: Ukrmedknyha; 2008. 424 p. [In Ukrainian].

2. Yermakova TV, Deikalo IM, Shydlouski AV. Surgical treatment of thyroid disease with the use of technology LigaSure. Clinical Endocrinology And Endocrine Surgery. 2015 May.2015;(2):37-40. https://doi org/10.24026/1818-1384.2(50).2015.74914. [In Ukrainian].

3. Larin OS. Standartyzatsiia pidkhodiv do likuvannia vuzlovoho zobu na osnovi patohenetychno dotsilnykh ta efektyvnykh metodiv - vymoha chasu u suchasnii endokrynolohii. Clinical Endocrinology And Endocrine Surgery. 2002;(3):109-16. [In Ukrainian].

4. Cherenko SM. Shliakhy poperedzhennia spetsyfichnykh uskladnen u khirurhii shchytopodibnoi ta pry shchytopodibnoi zaloz. Clinical Endocrinology And Endocrine Surgery. 2006;(4):5-6. [In Ukrainian].

5. Hegedüs L, Bonnema SJ, Bennedbæk FN. Management of Simple Nodular Goiter: Current Status and Future Perspectives. Endocr Rev. 2003 Feb;24(1):102-32.

https://doi.org/10.1210/er.2002-0016.

6. Palamarchuk VA, Cherenko SM, Laryn AS. Profylaktyka spetsyfycheskykh khyrurhycheskykh oslozhnenyi pry lechenyy dyffuznoho toksycheskoho zoba. Problemi Endokrinnoi Patologii. 2003;(2):47-51. [In Russian].

7. Gharib H, Papini E, Garber JR, Duick DS, Harrell RM, Laszlo Hegedüs L, et al. American Association Of Clinical Endocrinologists, American College Of Endocrinology, And Associazione Medici Endocrinologi Medical Guidelines For Clinical Practice For The Diagnosis And Management Of Thyroid Nodules-2016 Update. Endocr Pract. 2016 May;22(5):622-39.

https://doi.org/10.4158/EP161208.GL

8. Braverman LI. Bolezni shhitovidnoj zhelezy. Perevod s anglijskogo. Moskva: Medicina; 2000. 417 p. [In Russian].

9. Cherenko MP. Oslozhnenija pri operacijah na shhitovidnoj zheleze. Kiev: «Zdorovia»; 1977. 110 p. [In Russian].

10. Liulka AN, Liahovskii VI, Kovalev AP. Prichiny neudovletvoritel'nyh kosmetichesikh rezultatov posle operacij po povodu zoba. Klin khir. 2012 Lyst; (11):22. [In Russian].

11. Kovalov OP, Liulka OM, Liakhovskyi VI, Kulyk OV, vynakhidnyky; VDNZU "UMSA", patentovlasnyk. Sposib drenuvannia pisliaoperatsiinoi rany pry operatsiiakh z pryvodu zoba. Patent Ukainy No 63286. 2011 Zhov 10. [In Ukrainian]. 